GRADIATION\&APPLICATIONS

ISSN 2466-4294 (online) | rad-journal.org

Vol. 3 | Issue 1 | pp. 59-63, 2018

doi: 10.21175/RadJ.2018.01.011

Original research paper

\title{
SUBLETHAL X-RAY IRRADIATION INDUCES GENETIC INSTABILITY IN HUMAN ENDOMETRIAL MESENCHYMAL STEM CELLS AT THE KARYOTYPE LEVEL*
}

\author{
Tatiana Grinchuk $^{\mathbf{1}^{* *}}$, Mariia Shilina1, Zoya Kovaleva1, Nikolay Nikolsky² \\ ${ }^{1}$ Group of Genetic Mechanisms of Cell Differentiation and Malignization, Institute of Cytology, Russian Academy of \\ Science, St. Petersburg, Russia \\ 2 Department of Intracellular Signalling and Transport, Institute of Cytology, Russian Academy of Science, \\ St. Petersburg, Russia
}

\begin{abstract}
We aimed to study the karyotype structure of human adult stem cells after X-ray irradiation. Cultured endometrial mesenchymal stem cells (eMSC) isolated from desquamated endometrium of menstrual blood of the healthy woman were the object of this research. The eMSC at the $9^{\text {th }}$ passage were irradiated with the sublethal $X$-ray dose (5Gy). Irradiated cells were cultivated under standard conditions and, at the $13^{\text {th }}$ passage, they underwent to the karyotyping assay with the G-banding technique. The cytogenetic analysis revealed that the progeny of irradiated cells exhibited genetic instability. Most of analyzed cells had chromosomal abnormalities. Karyotypic changes were manifested mostly as aneuploidy and near-centromeric and other breaks. Within a particular karyotype, various chromosomes may be involved in breaks. Chromosome 1, 4 and $X$ were not involved in chromosomal rearrangements randomly. About $80 \%$ of the control not irradiated eMSC metaphase plates had the standard karyotype at the same $13^{\text {th }}$ passage. Deviations from the normal karyotype were random. Chromosomal breaks were not observed. Our findings show that sublethal X-ray irradiation of eMSC resulted in multiple disorders of the genetic apparatus at the karyotype level. The cells that survived irradiation entered replicative senescence and avoided immortalization or transformation.
\end{abstract}

Key words: Human stem cells, irradiation, $X$-rays

\section{INTRODUCTION}

Ionizing radiation is an important type of exogenous stress that can induce changes in the cell genome [1]-[4]. Results of X-ray and gamma radiation can be gaps in one or two strands of DNA, the damage of its secondary structure, the formation of intra- and intermolecular crosslinks, the destruction of certain amino acids in proteins and nucleic acids bases. The modified DNA structure underlies the irradiation mutagenic and carcinogenic effect. The cells that retained mitotic activity had various types of karyotypical disorders: nuclear pyknosis, preudomitosis, cell division disorder and various chromosomal abnormalities. Morphological aberrations are presented as acentric fragments, dicentric and ring chromosomes, chromatid fragments and spaces [5]-[7]. Human lymphocytes irradiated by gamma-rays in the dose of 4.27 Gy exhibited changes in the karyotype structure (centric rings and fragments) in $90 \%$ of the cells [8]. At X-ray irradiation with the dose of $1 \mathrm{~Gy}, 28 \%$ of the cells had changes in the karyotype structure whereas, in the control, the adjustment met only $3 \%$ of the cells [9]. According to the studies on the Chernobyl accident, the number of human lymphocytes containing chromosomal aberrations was 4-6 times higher than the control level. The most common types of aberrations were single and paired fragments [10]. In liquidators irradiated with doses higher than $20 \mathrm{~Gy}$, the frequency of dicentric chromosome and chromosomal rings significantly exceeded the control values. The cytogenetical analysis identified that chromosome 4 was repeatedly involved in rearrangements as the result of irradiation [11]-[14]. These data are of particular importance in connection with the use of $\mathrm{X}$-rays in the clinic.

The purpose of this work was to study the influence of the X-ray sublethal dose on the karyotype of human mesenchymal stem cells in culture.

\section{MATERIALS AND METHODS \\ 2.1. Biological material}

The study was performed on cultured endometrial mesenchymal stem cells (eMSC) derived from desquamated endometrium in the menstrual blood

\footnotetext{
* The paper was presented at the Fifth International Conference on Radiation and Applications in Various Fields of Research (RAD 2017), Budva, Montenegro, 2017.

grintat@bk.ru
} 
T. Grinchuk et al., Sublethal X-ray irradiation induces genetic instability..., Rad. Applic., 2018, 3, 1, 59-63

[15]. The cells were cultivated in the DMEM/F12 medium (Gibco, United States) with 10\% bovine fetal serum (HyClone, United States), 1\% antibioticantimycotic solution and 1\% GlutaMAX (Gibco, United States) with $5 \% \mathrm{CO}_{2}$ at $37^{\circ} \mathrm{C}$.

\subsection{Irradiation}

MSC at the $9^{\text {th }}$ passage were irradiated with X-rays in the dose of $5 \mathrm{~Gy}$. The dose is sublethal and about 20 $\%$ cells remained viable. Irradiated cells were cultivated under standard conditions. At the $4^{\text {th }}$ passage after irradiation (in total, cells have gone through 13 passages), they underwent to karyotyping assay with the G-banding technique.

\subsection{G-banded karyotyping}

Colcemid (stock solution $10 \mathrm{mg} / \mathrm{mL}$ ) (Sigma, United States) was added to the cell culture that reached a confluence of $80 \%$ for $1-1.5 \mathrm{~h}$. at $37^{\circ} \mathrm{C}$. Then, the medium was removed, cells were detached with 0.05\% trypsin (Biolot, Russia) and centrifuged (1300 rpm). The pellet was suspended and treated with $0.075 \mathrm{M} \mathrm{KCl}$ hypotonic solution for about $1 \mathrm{~h}$. The cell suspension was centrifuged, the sediment was resuspended and fixed by methanol mixed with acetic acid 3:1. The fixator was changed three times, the total fixation time was $1.5 \mathrm{~h}$. The fixed cell suspension was dropped on cold and wet slides. The slides were airdried for one week. Then, the chromosomes were Gbanded with the Giemsa stain (Fluka, United States) after the preliminary trypsinization. Metaphase plates with well-spread chromosomes were assayed under the microscope Axio Scop (Carl Zeiss, Germany), objective $100 \times$, ocular 20×. The chromosomes were identified according to the international nomenclature [16] and the atlas of human chromosomes [17].

\subsection{SA- $\beta$-Gal activity}

The enzyme activity is a marker of cellular senescence. $10^{5}$ cells were plated in $3 \mathrm{~cm}$ Petri dishes and cultivated for 3 days. Then, the medium was removed, cells were washed with PBS (Sigma, United States), fixed with $4 \%$ formaldehyde and stained with senescence-galactosidase staining kit (Cell Signalling, United States) according to the manufacturer's instructions. SA- $\beta$-Gal activity was detected by cell blue staining and visualized under a microscope.

\section{RESULTS AND DISCUSSION}

The cytogenetic analysis revealed that the progeny of irradiated cells exhibited genetic instability. Most of analyzed cells had chromosomal abnormalities (Table). Most types of karyotypic changes were aneuploidy evident as one or three chromosome copies and chromosome breaks both in near-centromere regions and other regions (see Table 1, 2) . Chromosomes 1, 4 and $\mathrm{X}$ were engaged in chromosomal rearrangements not randomly (see Figure 1). It should be noted that the medical examination of Chernobyl liquidators revealed chromosome abnormalities in the peripheral blood lymphocytes with chromosome 4 being the most frequently involved [14].

60
Table 1. Changes in copies of chromosomes and chromosome arms in eMSC survived X-ray irradiation

\begin{tabular}{|c|c|c|}
\hline \multirow[t]{2}{*}{$\begin{array}{c}\text { CHROMOSOME } \\
\text { NUMBER }\end{array}$} & \multicolumn{2}{|c|}{$\begin{array}{c}\text { QUANTITY OF METAPHASES } \\
\text { WITH COPIES CHANGES IN } \\
\text { 30 ANALYZED PLATES }\end{array}$} \\
\hline & 1 copy & 3 copies \\
\hline 1 & - & $1 ; 3 \mathrm{p}^{*} ; \mathrm{q}^{* * *}$ \\
\hline 2 & - & 1 \\
\hline 3 & - & 1 \\
\hline 4 & 2 & - \\
\hline 5 & 5 & $5 ;$ qter $^{* * *}$ \\
\hline 6 & - & 2 \\
\hline 7 & - & 2 \\
\hline 8 & 3 & - \\
\hline 9 & 6 & - \\
\hline 10 & 2 & 2 \\
\hline 11 & 3 & $3 ; \mathrm{q}$ \\
\hline 12 & 6 & - \\
\hline 13 & 6 & 3 \\
\hline 14 & 2 & 5 \\
\hline 15 & - & 4 \\
\hline 16 & 4 & 1 \\
\hline 17 & 2 & 2 \\
\hline 18 & 4 & 2 \\
\hline 19 & - & - \\
\hline 20 & 3 & 3 \\
\hline 21 & 9 & - \\
\hline 22 & 9 & - \\
\hline $\mathrm{X}$ & 7 & - \\
\hline
\end{tabular}

* p-chromosome short arm; ** q-chromosome long arm; **** qter-terminal part of chromosome long arm

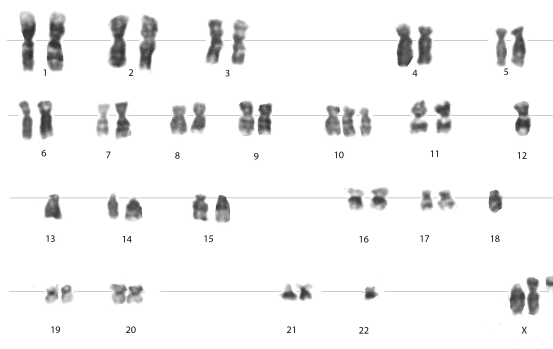

b

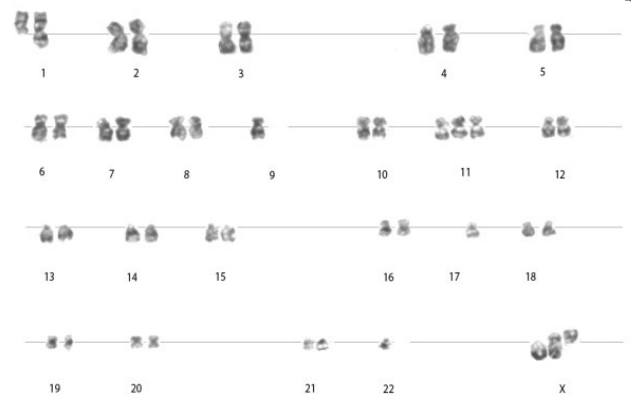

Figure 1. Karyotypes eMSC $4^{\text {th }}$ passage after X-ray irradiation. In total, cells have gone through 13 passages. a -nearcentromere breakage of chromosome X; trisomy of chromosome 10; monosomy of chromosomes 12,13,18,22. $\mathrm{b}$ - near-centromere breakage of chromosomes 1 , X; trisomy of chromosome 11; monosomy of chromosomes 9, 17 and 22 . 
T. Grinchuk et al., Sublethal X-ray irradiation induces genetic instability..., Rad. Applic., 2018, 3, 1, 59-63

Table.2. Karyotype changes in eMSC survived X-ray irradiation

\begin{tabular}{|c|c|c|c|c|c|c|c|c|c|c|c|c|}
\hline \multirow{2}{*}{$\begin{array}{c}\text { PLATE } \\
\text { NUMBE } \\
\text { R OF }\end{array}$} & \multicolumn{9}{|c|}{ CHROMOSOMES HAVING BREAKS } & \multirow[t]{2}{*}{$\begin{array}{l}\text { TRANS } \\
\text { LOCAT } \\
\text { ION }\end{array}$} & \multicolumn{2}{|c|}{$\begin{array}{c}\text { COPY } \\
\text { CHANGES IN } \\
\text { CHROMOSOM } \\
\text { AL MATERIAL }\end{array}$} \\
\hline & 1 & 2 & 3 & 4 & 5 & 6 & 10 & 12 & $\mathrm{X}$ & & $\begin{array}{c}\text { Monos } \\
\text { omy }\end{array}$ & $\begin{array}{c}\text { Triso } \\
\text { my }\end{array}$ \\
\hline 1 & - & - & - & $p+q$ & - & - & - & - & - & - & + & + \\
\hline 2 & - & - & - & - & - & - & - & - & - & - & + & + \\
\hline 3 & delq & - & - & - & - & - & - & - & - & - & + & + \\
\hline 4 & - & - & - & - & - & - & - & - & delqter & - & - & + \\
\hline 5 & $\begin{array}{l}\text { delp; } \\
2 \mathrm{~N}+\mathrm{q}\end{array}$ & - & - & - & - & - & - & - & delq & - & + & + \\
\hline 6 & - & - & - & - & - & - & - & - & - & - & + & + \\
\hline 7 & $p+q$ & $2 \mathrm{~N}+\mathrm{q}$ & - & - & - & - & - & - & delqter & - & + & + \\
\hline 8 & - & - & - & - & - & - & - & - & - & $\operatorname{tr} 14: 17$ & + & + \\
\hline 9 & - & - & - & - & - & - & - & - & - & - & + & + \\
\hline 10 & - & - & - & - & - & - & - & - & - & - & + & - \\
\hline 11 & delqter & - & - & delq & - & - & - & - & 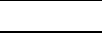 & - & + & + \\
\hline 12 & - & - & - & - & - & - & - & delqter & - & - & + & + \\
\hline 13 & - & - & - & - & - & delqter & - & - & $p+q$ & - & + & + \\
\hline 14 & - & - & - & - & - & - & - & - & $p+q$ & - & + & + \\
\hline 15 & - & - & - & - & - & delqter & - & - & - & - & + & + \\
\hline 16 & delpter & - & - & - & - & & & - & - & - & + & + \\
\hline 17 & delqter & - & - & delqter & - & - & & - & - & - & + & + \\
\hline 18 & delq & - & - & - & - & - & & - & - & - & + & + \\
\hline 19 & - & - & - & - & - & - & & - & $p+q$ & - & + & + \\
\hline 20 & - & - & - & - & - & - & & - & - & - & + & + \\
\hline 22 & - & - & delpter & - & - & - & & - & - & - & + & + \\
\hline 23 & - & - & - & delqter & - & - & delqter & - & - & - & + & + \\
\hline 24 & - & - & - & $\mathrm{p}+\mathrm{q}$ & $\begin{array}{c}\text { del } \\
p+2 / 3 \\
q\end{array}$ & - & - & - & - & - & + & + \\
\hline 25 & - & - & - & - & - & - & - & - & $p+q$ & - & + & + \\
\hline 26 & - & - & - & - & - & - & - & - & - & - & + & - \\
\hline 27 & - & & - & - & - & - & - & - & - & - & + & + \\
\hline 28 & - & & - & - & - & - & - & - & - & - & + & + \\
\hline 29 & - & - & - & - & - & - & - & - & - & - & + & - \\
\hline 30 & - & - & - & - & - & - & - & - & - & - & + & + \\
\hline
\end{tabular}

$\mathrm{p}$-chromosome short arm; q-chromosome long arm; ter-terminal part of chromosome; del - deletion; $\operatorname{tr}-\operatorname{translocation;~} \mathrm{p}+\mathrm{q}-$ near centromeric break without chromosomal material loss; $2 \mathrm{~N}-2$ normal copies; ter - terminal part of del p+2/3q - deletion of p-arm and $2 / 3$ of q-arm

The control, not irradiated eMSC at the $13^{\text {th }}$ passage, had normal karyotype in $80 \%$ of the cases. Deviations from the normal karyotype were random. Chromosomal breaks were not registered (see Figure 2).

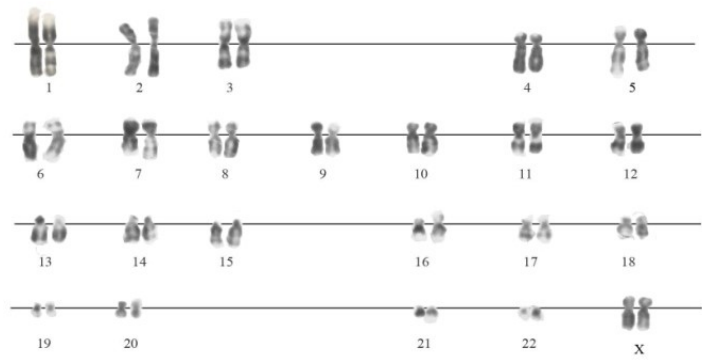

Figure 2. Normal G-banded eMSC karyotype, passage 13
Interestingly, that pattern of karyotyping changes evoked by X-rays in eMSC was later comparable with cytogenetic changes in these cells after the heat shock [18].

We provide evidence that the sublethal X-ray irradiation of eMSC results in the destabilization of the karyotype. Karyotypic changes in these cells did not cause their immortalization or transformation in vitro. Cells exposed to irradiation resumed proliferation and were able to divide during 6 passages after treatment. Totally they underwent 15 passages and then stopped to proliferate. Most cells (90\%) in these cultures were positively stained with SA- $\beta-$ Gal (see Figure $3 \mathrm{~A}$ ) which is an indication of the replicative senescence. At this moment untreated cells underwent approximately the same population doublings and also entered into the replicative senescence (Fig. $3 \mathrm{~B}$ ). 
T. Grinchuk et al., Sublethal X-ray irradiation induces genetic instability..., Rad. Applic., 2018, 3, 1, 59-63

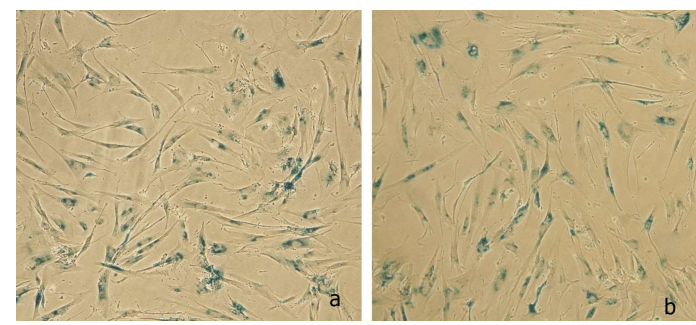

Figure 3. SA- $\beta$-Gal staining. A - long-term cultivated of eMSC survived X-ray irradiation; B-long-term cultivated untreated eMSC

Our findings show that X-rays induce karyotypic abnormalities involved preferentially chromosomes 1 , 4 , X. It should be kept in mind that the use of X-ray irradiation, which is widely used for therapeutic and diagnostic purposes, may be risky.

Acknowledgement: The paper is a part of the research done within the project 14-50-00068 (by Russian Scientific Foundation).

\section{REFERENCES}

1. Y. Kodama et al., "Stable chromosome aberrations in atomic bomb survivors: Results from 25 years of investigation." Radiat. Res., vol. 156, no. 4, pp. 337 346, Jun. 2001

DOI: $10.1667 / 0033^{-}$

7587(2001)156[0337:SCAIAB]2.o.CO;2

2. M. Nakano, Y. Kodama et al., "Detection of stable chromosome aberrations by FISH in A-bomb survivors: Comparison with previous solid Giemsa staining data on the same 230 individuals," Int. J. Radiat. Biol., vol. 77, no. 9, pp. $971-977$, Sep. 2001.

DOI: $10.1080 / 09553000110050065$

PMid: 11576457

3. L. Stoilov, M. Georgieva, V. Manova, L. Liu, K. Gecheff, "Karyotype reconstruction modulates the sensitivity of barley genome to radiation-induced DNA and chromosomal damage," Mutagenesis, vol. 28, no. 2, pp. $153-160$, Mar. 2013.

DOI: $10.1093 /$ mutage/geso65 PMid: 23221036

4. K. Ohtaki et al., "Human fetuses do not register chromosome damage inflicted by radiation exposure in lymphoid precursor cells except for a small but significant effect at low doses," Radiat. Res., vol. 161, no. 4, no. 373 - 379, Apr. 2004.

DOI: $10.1667 / 3147$

5. B. Ponnaiya et al., "The evolution of chromosomal instability in Chinese hamster cells: a changing picture?” Int. J. Radiat. Biol., vol. 74, no. 6, pp. $765-$ 770, Dec. 1998.

DOI: $10.1080 / 095530098141041$

PMid: 9881722

6. K. Suzuki, R. Takahara, S. Kodama, M. Watanabe, "In situ detection of chromosome bridge formation and delayed reproductive death in normal human embryonic cells surviving X irradiation," Radiat. Res. vol. 150, no. 4, pp. $375-381$, Oct. 1998.

DOI: $10.2307 / 3579655$

PMid: 9768850

7. S. Salomaa, K. Holmberg, C. Lindholm, R. Mustonen, M. Tekkel, T. Veidebaum, B. Lambert, "Chromosomal instability in in vitro radiation exposed subjects," Int. $J$. Radiat. Biol., vol. 74, no. 6, pp. 771 - 779, 1998.

DOI: $10.1080 / 095530098141050$
PMid: 9881723

8. И. К. Хвостунов и др., “Анализ хромосомных аберраций в клетках млекопитающих при воздействии различных видов ионизирующего излучения," Радиация и риск, т. 22, но. 4, стр. $43-$ 59, 2013. (I. K. Khvostunov et al., "Analysis of chromosome aberrations in mammalian cells under the action of various types of ionizing radiation," Radiation and Risk, vol. 22, no. 4, pp. 43 - 59, 2013.)

Retrieved from: http://radiation-andrisk.com/images/pdf/rr 13 4 8.pdf; Retrieved on: Jan. 26, 2018

9. Н. Л. Шмакова, Е.А. Насонова, Е. А. Красавин, Л. А. Мельникова, Т.А. Фадеева, “Индукция хромосомных аберраций и микроядер в лимфоцитах периферической крови человека при действии малых доз облучения," Радиационная биология. Радиоэкология, т. 46, но. 4, стр. 480 - 487, 2006. (N. L. Shmakova, E. A. Nasonova, E. A. Krasavin, L. A. Melnikova, T. A. Fadeeva, "The induction of chromosome aberrations and micronuclei in human peripheral blood lymphocytes at low doses of radiation," Radi. Radioecology, vol. 48, no. 4, pp. 480 $-487,2006$.

10. Ю.Н. Шишмарев и др., "Клинические аспекты последствий аварии на Чернобыльской АЭС," Радиобиология, т. 32, но. 3, стр. 323 - 332, 1992. (Yu. N. Shishmarev et al., "Clinical Aspects of the Consequences of the Chernobyl Accident," Radiobiology, vol. 32, no. 3, pp. 323-332, 1992.)

11. S. Knehr, H. Zitzelsberger, H. Braselmann, U. Nahrstedt, M. Bauchinger, "Chromosome analysis by fluorescence in situ hybridisation: further indications for a non-DNA-proportional involvement of single chromosomes in radiation-induced structural aberrations," Int. J. Radiat. Biol., vol. 70, no. 4, pp. 385 - 392, Oct. 1996.

DOI: $10.1080 / 095530096144851$

PMid: 8862449

12. J. J. W. A. Boei, S. Vermeulen, A. T. Natarajan, "Different involvement of chromosomes 1 and 4 in the formation of chromosomal aberrations in human lymphocytes after X-irradiation," Int. J. Radiat. Biol., vol. 72, no. 2, pp. 139 - 145, Aug. 1997.

DOI: $10.1080 / 095530097143356$

PMid: 9269306

13. G. Stephan, S. Pressl, "Chromosome aberrations in human lymphocytes analysed by fluorescence in situ hybridisation after in vivo irradiation, and in radiation workers, 11 years after an accidental radiation exposure,” Int. J. Radiat. Biol., vol. 71, no. 3, pp. 293 299, Mar. 1997.

DOI: $10.1080 / 095530097144175$

PMid: 9134019

14. А.Н. Богомазова, "Изучение стабильных и нестабильных хромосомных аберраций у лиц, пострадавших в результате аварии на ЧАЭС, в отдаленный пострадиационный период," Дисс. канд. биол. наук, Центральный научноисследовательский рентгенорадиологический институт, Санкт-Петербург, Россия, 2000. (A. N. Bogomazova, "The study of stable and unstable chromosomal aberrations in persons affected by the Chernobyl accident in the remote post-radiation period," Cand. Sc. dissertation, Central Research Institute of Radiology, St-Petersburg, Russia, 2000.)

15. V. I. Zemelko et al., "Multipotent mesenchymal stem cells of desquamated endometrium: isolation, characterization and use as feeder layer for maintenance of human embryonic stem cell lines," Tsitologija, vol. 53, no. 12, pp. 919 - 929, 2011.

DOI: 10.1134/S1990519X12010129

PMid: 22359950 
T. Grinchuk et al., Sublethal X-ray irradiation induces genetic instability..., Rad. Applic., 2018, 3, 1, 59-63

16. ISCN 1995 An International System for Human Cytogenetic Nomenclature, Recommendations of the ISCN, ISCN, Basel, Switzerland, 1995.

17. С. Е. Мамаева, Атлас хромосом постоянных клеточных линий человека и животных, Москва, Россия: Научный Мир, 2002. (S. Е. Mamaeva, Atlas chromosomes permanent cell lines of human and animals, Moscow, Russia: Sci. World, 2002.)

18. М.А. Шилина, “Физиологическая и генетическая характеристика эндометриальных мезенхимных стволовых клеток человека в культуре,” дисс. канд. биол. наук., Институт цитологии Российской академии наук, Санкт-Петербург, Россия, 2017.
(M.A. Shilina, "Physiological and genetic characteristic of human endometrial mesenchymal stem cells in culture," Cand. Sc. Dissertation, Institute of Cytology of the Russian Academy of Sciences, St-Petersburg, Russia, 2017.)

Retrieved form: http://docplayer.ru/71738775-Shilinamariya-aleksandrovna-fiziologicheskaya-i-

geneticheskaya-harakteristika-endometrialnyhmezenhimnyh-stvolovyh-kletok-cheloveka-v-

kulture.html;

Retrieved on: Jan. 25, 2018 